\title{
FINGIMENTOS DRAMÁTICOS, EM CINCO CENAS E SEM FINAL...
}

http://dx.doi.org/10.11606/issn.2175-3180.v12i23p209-212

Edson Santos Silva ${ }^{\mathrm{I}}$

Para Lilian Lopondo e Francisco Maciel Silveira (in memoriam)

\section{CENA 1: PORQUE ENQQUANTO HOUVER TEATRO EU RESSUSCITO...}

Enquanto houver teatro eu ressuscito

No drama

No trágico

No épico

Fiz minhas promessas e com elas creiam: cheguei aos mares do fim do mundo

De tensões dramáticas me vesti

Mas as cortinas sempre se abrem para além dos salazares e dos caetanos

Do mesmo tablado se pode ver o bailarino e a excomungada

Porque enquanto houver teatro eu ressuscito.

Meus lugres se revestem de cravos e perfumado com eles imagino aldeias velhas

Aos poucos sou tomado de uma tal euforia e no sangue das palavras que se estende até as cortinas daquele teatro vejo crimes e vejo em Alfama muitos édipos...

Anjos de carne e osso, os anjos sempre com o sangue

Duelos. Ser dramaturgo e ser português e ter 45 anos de idade é viver a duelar!

\footnotetext{
I Universidade Estadual do Centro-Oeste do Paraná/UNICENTRO/I, Paraná, Brasil.
} 
Os inquisidores amam o fogo? Dou a eles o inferno e a carne poética do Judeu.

Afinal, a história precisa se alimentar do sacrifício dos inocentes

A Imolação diante da presença ausência de Deus!

Porque enquanto houver teatro eu ressuscito.

Entre a traição do meu Padre Martinho e os marginais e a revolução há um punho que é maior que os meus mares do fim do mundo Porque enquanto houver teatro eu ressuscito...

\section{CENA 2: PORQUUE NA ETERNIDADE AS CORTINAS NÃO SE FECHAM...}

Nasci nos versos Rosário, me fiz na cena Santareno

Nos entre(s)actos o eterno menino da mãe a fugir do homem do pai

Mas a vida dói

Sempre a morte na raiz

Sempre nas sombras os olhos da víbora e o perene mar

Sal e sangue

Me vejo na gaivota perdida

Não, não, não

Não me peçam gestos medidos

Eternamente arlequim

Nem santo

Nem herói

Nem mestre

Eu sou dramaturgo

Posso dar apenas dramas e canções e no vento triste, meu destino

A vida me dói

Mas sei que na eternidade as cortinas não se fecham...

\section{CENA 3: VERDE QUE TE QUERO TEJO E RIBATEJO...}

Espinheiro

Aldeias

Observo o povo

Meu lema: liberdade

Vejo o belo apenas nas profundezas do mar

Vasculho nas algas as almas dos meus

Estou de corpo 
sargaços

Volto com alma e a palavra se ergue brada e grita:

"que a palavra/palco (não) seja lâmina"

Que corpos distantes eu vejo perto em cena agora?

Sou um devaneio e sigo minha ascese mítica e minhas ligações telúricas com minhas terras

Verde que te quero Tejos...

\section{CENA 4: PERGUNTEM AO MEU TEATRO...}

Não a um teatro de mortos para mortos;

Não a um teatro contente, digestivo malandreco;

Não aos gemidinhos entrecortados de "chichis" em penico de louça das Caldas;

Meu teatro é bofetada...

A alma portuguesa só pode acordar do marasmo por meio do teatro;

Meu teatro é arma de intervenção;

Lorca, Ibsen, Brecht

Amem um pouco mais as nossas tentativas de fazer teatro!

Sejam generosos com o teatro!

E fora a todos os sátrapas!

Sou sim um médico-literário...

Minha sintaxe dramática sempre a luta pela liberdade.

Meus anjos estão feridos e marcados pela fatalidade

A pulsão criadora e tanática e violenta e às vezes estilhaça forma, linguagem e conteúdo...

e estilhaça a mim!

Sou trágico! Sou épico! O eu no social! Sagrado e profano!

Falhamos todos?

Perguntem ao meu teatro...

\section{CENA 5: DESLUMBRAMENTOS ÉPICOS...}

Sala escura e ao fundo música Grândola, Vila Morena

Voz em off numa quase simultaneidade de vozes de duas personagens apenas conhecidos como F e L. 
Enquanto a plateia escuta as vozes, focos de luz aparecem em várias partes do palco e se vê

placas nas quais nomes de grandes dramaturgos portugueses aparecem (Gil Vicente, António José da Silva, Almeida Garrett etc.)

Vozes: seu teatro é um caos de possibilidade...

Sua técnica era de um choque para galvanizar um público embotado... Ele queria fazer o público pensar e julgar...

Ao invés de desfecho, ele propunha tensão permanente...

Nada de catarse, claro. O teatro tinha de estar em diapasão com a vida... Intercalando as vozes acima, bem ao longe ainda se ouve a canção e o tempo todo focos de luz com placas e mais nomes de dramaturgos...

Vozes: Ele acreditava num mundo possível de modificação...

De repente, palmas e os focos de luz se ampliam, e ao centro do palco uma silhueta toma forma e num tipo do jogo esconde-esconde diz:

Sou português, escritor, tenho cem anos de idade e me chamo Bernardo Antonio Martinho do Rosário Santareno

No momento dessa fala, os focos de luz projetam em todas as paredes do espaço os nomes dos dramaturgos que ao longo da cena apareceram nos cartazes. Destaque: Santareno ao meio. Surgem então duas silhuetas, certamente das personagens $\mathrm{F}$ e L embaladas por uma canção que não se distingue se é a mesma que abriu a cena ou se é a voz de Amália Rodrigues cantando bem ao longe, muito ao longe, a canção Partindose. Vê-se uma luz delicadamente se extinguindo e F e L ornando com uma coroa de louros a cabeça de Antonio Martinho do Rosário, nada mais se vê mas sabe-se que a cena continua...

Recebido em 13 de outubro de 2020

Aprovado em 6 de novembro de 2020

Licença: (ㄷ) (i) ()

Edson Santos Silva

Professor Associado de Literatura Portuguesa da Universidade Estadual do Centro-Oeste do Paraná/UNICENTRO/I. Doutor e Mestre em Literatura Portuguesa pela Universidade de São Paulo.

Contato: jeremoabo21@gmail.com

(D): https://orcid.org/0000-0002-5921-7883 